\title{
Characteristics of myocardial infarction in young patients at Dr. Cipto Mangunkusumo Hospital, Jakarta
}

N.Abdurahman, M.Hutabarat, S.Harun

\begin{abstract}
Abstrak
Penyakit jantung koroner ( $P J K)$ merupakan penyebab kematian tertinggi di negara industri. Di negara berkembang, termasuk Indonesia, terjadipeningkatan frekwensi PJK. Prevalensi IM (infark miokard) pada laki-laki usia < 45 tahun menurut studi Framingham, adalah 75 per 1000 dibandingkan pada umur $>65$ tahun sebesar 212 per 1000 dalam 8 tahun. Faktor-faktor yang umumnya menonjol pada pasien IM usia muda adalah merokok, riwayat penyakit keluarga, dan dislipidemia, Lp (a). Metode dan cara kerja :Penelitian retrospektif pada semua pasien IMA yang dirawat di ICCU, RSUPN Dr Cipto Mangunkusumo, Jakarta dari tanggal 1 Januari 1990 sampai 31 Desember 1994 sejumlah 642 orang. Hasil penelitian : dari 642 kasus didapatkan laki-laki sebanyak 531 orang (82,7\%)

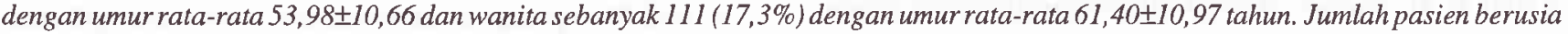
di bawah 45 tahun seluruhnya 94 orang $(14,6 \%)$ dengan umur rata-rata 38,54+5,63 tahun. Dari jumlah ini didapatkan laki-laki sebanyak 88 orang $(93,6 \%)$ dan wanita 6 orang $(6,4 \%)$. Faktor risiko pada usia $<45$ tahun adalah sebagai berikut : merokok, faktor keturunan, stress. Kesimpulan : Pasien IMA usia muda didapatkan lebih banyak pada laki-laki daripada wanita dengan perbandingan 93,6\% : 6,4\%. Faktor risiko yang ditemukan terutama adalah merokok dan stress.
\end{abstract}

\begin{abstract}
Coronary artery disease (CAD) is the most frequent cause of death in the industrialized countries. In developing countries, such as Indonesia, CAD showed an increase. According to Framingham's study, the prevalence of myocardial infarction (MI) in the last 8 years in males under 45 years of age was 75 per 1000 people, compared to those above 65 years of age with a ratio of 212 per 1000 people. The important risk factors in the young MI patients were smoking, family history of CAD and dyslipidemia, Lp (a). Materials and Methods: A retrospective study was done on all MI patients of the ICCU of Dr Cipto Mangunkusumo Hospital, from January I, 1990 to December 31, 1994, with a total of 642 cases. Results : Of the 642 cases, the number of male patients was found to be 531 $(82.7 \%)$ with average age of $53.98 \pm 10.66$, and 111 females $(17.3 \%)$ with average age of $61.40 \pm 10.97$. The number of patients under 45 years was $94(14.6 \%)$, with average age of $38.54 \pm 5.63$. Of this number, 88 patients $(93.6 \%)$ were males and 6 females $(6.4 \%)$. The risk factors of CAD in the age below 45 years were smoking, hereditary factor and stress. Conclusions: Young MI patients were found more in the male group than in female, with the ratio of $93.6: 6.4 \%$. The risk factors identified were mainly smoking and stress.
\end{abstract}

Keywords : Myocardial infarction, young people, risk factor

Coronary artery disease (CAD) is the most important cause of death in industrialized countries In the USA, $46 \%$ of all deaths in 1986 were caused by CAD. ${ }^{1}$ In Asian countries, CAD also became a major cause of death. In Singapore, for instance, deaths due to CAD had doubled in two decades since 1959. The same phenomenon was also found in Latin America. ${ }^{2}$ In Japan the increased frequency of CAD was assumed to be due to changes in dietary pattern. In the past, the incidence of myocardial infarction in Japan was much

Division of Cardiology, Department of Internal Medicine, Faculty of Medicine University of Indonesia, Jakarta, Indonesia lower than in the western countries. Between 1975 and 1979 in Tokai, Tokyo, there was only one myocardial infarction patient under 40 years of age and this number is increased to 3 between 1980 to $1985^{3}$

According to the 1985/1986 Household Health Survey, in Indonesia CAD was the second most common cause of death $(9.9 \%)$, but in the 1992 survey it has doubled to $16.6 \%{ }^{4}$ Of 523,000 subjects involved in the Monica Project conducted in the municipality of Jakarta in 1990, 2073 were randomly selected to take part in the study. Abnormal ECG was found in $2.7 \%$ of the population studied. ${ }^{5}$ An epidemiological study conducted in 1993 by the Division of Endocrinology, Faculty of Medicine University of Indonesia in Kayu 
Putih village, Jakarta, showed a $5.7 \%{ }^{6}$ Suyono predicted an increase in CAD incidence because of the change in dietary pattern, particularly in the big cities, from high fiber diet to a diet high in carbohydrate, protein and fat. ${ }^{7}$

In the USA, multiple CAD risk factor intervention initiated in the 1970s, has succeeded in sharply reducing CAD mortality rate to $3 \%$ annually. ${ }^{1}$ From 1971 to 1982 there was also a decline in the incidence of myocardial infarction, being $24 \%$ in man and $37 \%$ in women. Patients under 45 years of age showed twice as much as reduction in the incidence of myocardial infarction than those of over 45 years old. ${ }^{8}$

The prevalence of myocardial infarction in the young was relatively lower compared to the older population. The reported prevalence of myocardial infarction in patients below 45 years of age ranged from $3 \%$ to $10 \%$ in males and $0.3 \%$ to $2 \%$ in female. ${ }^{9-14}$ Framingham's study showed that the likelihood of myocardial infarction within 8 years in male subjects aged under 45 years was 75 in 1.000 , whilst in those aged above 65 years it was 212 in $1000 .^{14}$

In the National Cardiac Center, Jakarta, Hanafiah reported an increase in the incidence of myocardial infarction in patients under 45 years, from $7 \%$ in 1985 to $17 \%$ in $1989 .{ }^{11}$

The principal risk factors of myocardial infarction in the young patients were smoking, $, 10 ., 12,13,31$ positive family history, $9,12,13,32,33,34$ dyslipidemia, and Lp (a). Hypertension was not so prevalent in older people, ranging from 16.7 to $29 \%$, diabetes mellitus in the young was also less frequently found, being in the range of $3 \%$ to $6.3 \%$. One should take note, that in the literature "young age" was defined differently, i.e., from age below 35 years to below 60 years, while the mean value ranged from 40 to 45 years.

\section{MATERIALS AND METHODS}

\section{Population and sample}

A retrospective study was undertaken in all patients with acute myocardial infarction admitted at the ICCU, Dr. Cipto Mangunkusumo Hospital, Jakarta from January 1, 1990 to December 31, 1994.

\section{Statistical tests}

For quantitative data, mean and standard error of the mean (SEM) and standard deviation (SD) were measured. Statistical significance was set at a $p$ value of $<0.05$.

\section{RESULTS}

\section{Age and sex}

There were 642 myocardial infarction patients. Their ages ranged from 14 to 85 years with mean age of 55.26 years $(\mathrm{SEM} \pm 0.44$ year, $\mathrm{SD} \pm 11.06$ year $)$ and median age of 55 years. Of them, $531(82.7 \%)$ were males, with age ranging from 14 to 85 years, mean age was 53.98 years $(S E M \pm 0.46, S D \pm 10.66)$ and median age 53 years, while the number of females was $111(17.3 \%)$ patients with age ranging from 35 to 85 years, mean age was 61.40 years $(S E M \pm 1.04$ years, $\mathrm{SD} \pm 10.97$ ) and median age 60 years. Males were significantly younger than females, being 53.98 years $(\mathrm{SD} \pm 10.66)$ vs 61.40 years respectively $(\mathrm{SD} \pm 10.79$ years) $\mathrm{p}=0.000001$.

\section{Patients below 45 years old}

Ninety-four (14.6\%) patients were below 45 years old, their mean age was 39,54 years (SEM \pm 0.58 years $\mathrm{SD} \pm 5.63$ years) and median age was 40 years. Eighty-eight (93.8\%) patients were males and 6(6.4\%) were females. Mean age of male patients was 38.48 years (SEM \pm 0.617 years, $S D \pm 5,79$ year) and median age 40 years. The youngest male patient was 14 years old. Mean age of female patients was 39.50 years $(\mathrm{SEM} \pm 1.057$ years, $\mathrm{SD} \pm 2.59$ years) and median age 40.5 years. The youngest female patient was 35 years old.

\section{Patients over 45 years old}

The number of patients above 45 years old was 548 $(85.4 \%)$. The oldest patient was 85 years old. Mean age was 58.12 years (SEM \pm 0.39 years, $S D \pm 9.04$ years) and median age 45 years. Four hundred and fortythree $(80.8 \%)$ patients were males, the oldest was 85 year of age, their mean age was 57.05 years (SEM \pm 0.40 year, $S D \pm 8.50$ years ) and median age 56 years. The number of female patients was 105 (19.2\%), the oldest was 85 years old, their mean age was 62.69 years ( $\mathrm{SEM} \pm 0.93$ years $\mathrm{SD} \pm 9.50$ years ) and median age 65 years. The female-to-male ratio in the group of 
patients below 45 years old versus that of above 45 years old was $6.4 \%: 19.2 \%(\mathrm{p}=0.002)$.

\section{Occupation}

Occupational data were obtained from 564 (87.85\%) patients. Occupation was classified into: civil servants such as: member of parliament , bank official, lecturer, school teacher, judge, medical doctor, and nurse; private sector employee such as trader, entrepreneur, journalist, stock broker, retired people, blue-collar worker i.e. driver, brick layer, laborer; and unemployed people. The most common occupation was private sector employee $(32.3 \%)$, followed by civil servants $(19.1 \%)$, retired people $(17 \%)$, unemployed people (15.6\%) and blue collar workers (16\%).

\section{Time of onset}

Four hundred and eighty-seven patients $(75.86 \%)$ were admitted with a time of onset of less than 24 hours.

\section{Risk factors}

The most common risk factor was smoking (66.2\%), followed by hypertension $(47.2 \%)$, personality trait $(48,2 \%)$, stress ( $46.1 \%)$, history of diabetes mellitus ( $37.7 \%)$, obesity ( $28.1 \%)$, dyslipidemia (13.7\%), and genetic factor $(10.7 \%)$.

Table 1 showed the difference in $\%$ of risk factors between patients aged less than 45 versus those above 45 years of age.

\section{CLINICAL PRESENTATIONS}

\section{Chief complaints}

The most common complaints were chest pain, i.e., specific chest pain - anginal pain (86\%), followed by breathlessness $(5.6 \%)$, epigastric pain $(4 \%)$, severe condition $(3.1 \%)$, and miscellaneous complaints (1.1\%)

Table 1. Risk factors between AMI $<45$ years vs $\geq 45$ year subgroups

\begin{tabular}{lccccccl}
\hline Risk factors & \multicolumn{3}{c}{$<$ years } & \multicolumn{5}{c}{$\geq 45$ years } \\
& $\mathrm{N}$ & $\mathbf{n}$ & $\%$ & $\mathrm{~N}$ & $\mathrm{n}$ & $\%$ & $\mathrm{p}$ \\
\hline Hypertension & 94 & 29 & 30.9 & 548 & 274 & 50 & 0.0005 \\
History of DM & 89 & 12 & 13.5 & 515 & 117 & 22.7 & 0.049 \\
Glucose tolerance & 94 & 24 & 25.5 & 548 & 214 & 39.1 & $\mathrm{p}-0.012$ \\
Dyslipidemia & 72 & 9 & 12.5 & 440 & 56 & 12.7 & $\mathrm{NS}$ \\
Smoking & 94 & 75 & 79.7 & 9545 & 348 & 63.9 & 0.002 \\
Obesity & 94 & 33 & 35.1 & 535 & 144 & 26.9 & $\mathrm{NS}$ \\
Family history & 98 & 16 & 16.3 & 524 & 50 & 9.5 & 0.03 \\
Stress & 86 & 55 & 64 & 477 & 205 & 43 & 0.0003 \\
Personality A & 11 & 6 & 54.6 & 72 & 34 & 47.2 & $\mathrm{NS}$ \\
\hline
\end{tabular}

Table 2. Chief complaints

\begin{tabular}{lcccc}
\hline Chief complaints & $\begin{array}{c}\text { All } \\
\mathrm{n}=642\end{array}$ & $\begin{array}{c}<4 \text { years } \\
\mathrm{n}=94\end{array}$ & $\begin{array}{c}\geq 45 \text { years } \\
\mathrm{n}=598\end{array}$ & $\mathrm{p}$ \\
\hline Chest pain & $553(86.1 \%)$ & $86(91.5 \%)$ & $467(85.2 \%)$ & $\mathrm{NS}$ \\
Shortness of breath & $36(5.6 \%)$ & $3(3.2 \%)$ & $33(6.0 \%)$ & $\mathrm{NS}$ \\
Epigastric pain & $26(4.0 \%)$ & $3(3.2 \%)$ & $24(4.4 \%)$ & $\mathrm{NS}$ \\
severe condition* & $20(3.1 \%)$ & $1(1.1)$ & $19(3.5 \%)$ & $\mathrm{NS}$ \\
Miscellaneous & $7(1.1 \%)$ & $1(1.1 \%)$ & $19(3.5 \%)$ & $\mathrm{NS}$ \\
\hline
\end{tabular}

* severe conditions include : faint, fatigue, severely ill, shock, feet cyanosis

Miscellaneous: palpitation, diarrhea, cold sweat, post-PTCA, no complaint.

Chief complaints between patients aged $>45$ years and those aged $<45$ years did not differ significantly. 
Putih village, Jakarta, showed a $5.7 \%{ }^{6}$ Suyono predicted an increase in CAD incidence because of the change in dietary pattern, particularly in the big cities, from high fiber diet to a diet high in carbohydrate, protein and fat. ${ }^{7}$

In the USA, multiple CAD risk factor intervention initiated in the 1970s, has succeeded in sharply reducing CAD mortality rate to $3 \%$ annually. ${ }^{1}$ From 1971 to 1982 there was also a decline in the incidence of myocardial infarction, being $24 \%$ in man and $37 \%$ in women. Patients under 45 years of age showed twice as much as reduction in the incidence of myocardial infarction than those of over 45 years old. ${ }^{8}$

The prevalence of myocardial infarction in the young was relatively lower compared to the older population. The reported prevalence of myocardial infarction in patients below 45 years of age ranged from $3 \%$ to $10 \%$ in males and $0.3 \%$ to $2 \%$ in female. ${ }^{9-14}$ Framingham's study showed that the likelihood of myocardial infarction within 8 years in male subjects aged under 45 years was 75 in 1.000 , whilst in those aged above 65 years it was 212 in $1000 .^{14}$

In the National Cardiac Center, Jakarta, Hanafiah reported an increase in the incidence of myocardial infarction in patients under 45 years, from $7 \%$ in 1985 to $17 \%$ in $1989 .{ }^{11}$

The principal risk factors of myocardial infarction in the young patients were smoking, 9,10.,12, 13, 31 positive family history, 9, 12, 13, 32, 33, 34 dyslipidemia, and Lp (a). Hypertension was not so prevalent in older people, ranging from 16.7 to $29 \%$, diabetes mellitus in the young was also less frequently found, being in the range of $3 \%$ to $6.3 \%$. One should take note, that in the literature "young age" was defined differently, i.e., from age below 35 years to below 60 years, while the mean value ranged from 40 to 45 years.

\section{MATERIALS AND METHODS}

\section{Population and sample}

A retrospective study was undertaken in all patients with acute myocardial infarction admitted at the ICCU, Dr. Cipto Mangunkusumo Hospital, Jakarta from January 1, 1990 to December 31, 1994.

\section{Statistical tests}

For quantitative data, mean and standard error of the mean (SEM) and standard deviation (SD) were measured. Statistical significance was set at a $p$ value of $<0.05$.

\section{RESULTS}

\section{Age and sex}

There were 642 myocardial infarction patients. Their ages ranged from 14 to 85 years with mean age of 55.26 years $(\mathrm{SEM} \pm 0.44$ year, $\mathrm{SD} \pm 11.06$ year $)$ and median age of 55 years. Of them, $531(82.7 \%)$ were males, with age ranging from 14 to 85 years, mean age was 53.98 years (SEM $\pm 0.46, \mathrm{SD} \pm 10.66$ ) and median age 53 years, while the number of females was $111(17.3 \%)$ patients with age ranging from 35 to 85 years, mean age was 61.40 years (SEM \pm 1.04 years, $\mathrm{SD} \pm 10.97)$ and median age 60 years. Males were significantly younger than females, being 53.98 years $(\mathrm{SD} \pm 10.66)$ vs 61.40 years respectively $(\mathrm{SD} \pm 10.79$ years) $\mathrm{p}=0.000001$.

\section{Patients below 45 years old}

Ninety-four (14.6\%) patients were below 45 years old, their mean age was 39,54 years (SEM \pm 0.58 years $\mathrm{SD} \pm 5.63$ years) and median age was 40 years. Eighty-eight (93.8\%) patients were males and 6(6.4\%) were females. Mean age of male patients was 38.48 years (SEM \pm 0.617 years, $S D \pm 5,79$ year) and median age 40 years. The youngest male patient was 14 years old. Mean age of female patients was 39.50 years $(\mathrm{SEM} \pm 1.057$ years, $\mathrm{SD} \pm 2.59$ years) and median age 40.5 years. The youngest female patient was 35 years old.

\section{Patients over 45 years old}

The number of patients above 45 years old was 548 $(85.4 \%)$. The oldest patient was 85 years old. Mean age was 58.12 years (SEM \pm 0.39 years, $\mathrm{SD} \pm 9.04$ years) and median age 45 years. Four hundred and fortythree $(80.8 \%)$ patients were males, the oldest was 85 year of age, their mean age was 57.05 years (SEM \pm 0.40 year, $S \mathrm{SD} \pm 8.50$ years ) and median age 56 years. The number of female patients was 105 (19.2\%), the oldest was 85 years old, their mean age was 62.69 years ( $S E M \pm 0.93$ years $S D \pm 9.50$ years) and median age 65 years. The female-to-male ratio in the group of 


\section{Characteristics of chest pain}

There were 26 different characteristics of chest pain noted in 520 patients.

The most frequent chest pains were sensation of pressure $(36.5 \%)$, stabbing $(26.2 \%)$, burning $(9.0 \%)$, crushing $(5.4 \%)$, squeezing $(5 \%)$, and nonspecific chest pain $(18.1 \%)$. Nature of chest pain in the young age group compared to the older group was not statistically different.

\section{LABORATORY INVESTIGATION}

\section{Chest x-ray}

Data were collected from 368 patients. Cardiothoracic ratio (CTR) greater than 50\% was found in 166 subjects $(45.1 \%)$, while 202 patients $(54.9 \%)$ had CTR of less than $50 \%$. The difference between both groups was not significant $(\mathrm{p}=0.1816)$.

\section{Peak creatinine kinase (CK) value}

Four hundred and seventy-one patients had their peak $\mathrm{CK}$ values analyzed. The mean value was $925.33 \mu \mathrm{l}$ $(\mathrm{SD} \pm 1127.33 \mu \mathrm{l})$. Peak value in patients under 45 years of age was $1083.56 \mu \mathrm{l}(\mathrm{SD} \pm 1082.24 \mu \mathrm{l})$. Whereas in patients aged over 45 years, peak value was $895.36 \mu \mathrm{l}(\mathrm{SD} \pm 1134.52 \mu \mathrm{l})$. The difference between the two groups was statistically significant $(\mathrm{p}<0.05)$.

\section{Peak creatinine kinase muscle-brain (CKMB) value}

There were 465 subjects whose CKMB value could be analyzed. The mean was $81.82 \mu \mathrm{l}(\mathrm{SD} \pm 176.96 \mu \mathrm{l})$. Peak value in patients below 45 years of age was
$88.88 \mu \mathrm{l}(\mathrm{SD} \pm 118.94 \mu \mathrm{l})$, while those aged over 45 years was $80.48 \mu \mathrm{l}(\mathrm{SD} \pm 186.01 \mu \mathrm{l})$. The difference between both of groups was statistically significant $(\mathrm{p}<0.05)$.

\section{Leucocyte count}

Leucocyte count could be analyzed in 438 patients. Mean leucocyte count was $12385.3 / \mu \mathrm{l}$ (SD \pm $5265.6 / \mu \mathrm{l})$. In patients under 45 years of age the mean leucocyte was $13341 / \mu 1$ ( SD $\pm 5618.7 / \mu 1)$, while in patients of over 45 years old the mean count was $12209.5 / \mu \mathrm{l}(\mathrm{SD}+5187 \mu \mathrm{l})$, both groups differed significantly $(\mathrm{p}<0.05)$.

Mean leucocyte count in nonsurviving patients was $13218.2 / \mu \mathrm{l}(\mathrm{SD} \pm 4834.2 / \mu \mathrm{l})$, while the mean in surviving patients was $122239.7 / \mu \mathrm{l}(\mathrm{SD} \pm 4435.3 / \mu 1$. The difference between the two group did not reach statistical significance $(\mathrm{p}=0.31)$.

\section{DISCUSSION}

\section{Age and sex}

In the males, the youngest patient was 14 years old. The prevalence increased by age and the highest prevalence was in age group of 45-54 years old.

The youngest female patient 35 years old. The highest frequency was in the age group of 60-64 years and decreased from age of 55.26 years. The highest incidence took place in the group of 50-60 years old. In the Framingham's study, ${ }^{26}$ in which a population of 35-85 years old was followed-up for 26 year, the incidence of myocardial infarction was found to increase with aging. The highest incidence was in the age group of 75-85 years in both genders.

Table 3. Characteristics of chest pain

\begin{tabular}{lcccc}
\hline Characteristics & $\begin{array}{c}\text { All } \\
\mathrm{n}=52\end{array}$ & $\begin{array}{c}<45 \text { years } \\
\mathrm{n}=78\end{array}$ & $\begin{array}{c}\geq 45 \text { years } \\
\mathrm{n}=44\end{array}$ & $\mathrm{p}$ \\
\hline pressure & $189(36.4 \%)$ & $31(39.74 \%)$ & $158(35.7 \%)$ & $\mathrm{ns}$ \\
stabbing & $136(26.2 \%)$ & $21(26.92 \%)$ & $115(26 \%)$ & $\mathrm{ns}$ \\
burning & $47(9.0 \%)$ & $8(10.25 \%)$ & $39(8.8 \%)$ & $\mathrm{ns}$ \\
crushing & $28(5.4 \%)$ & $2(2.56 \%)$ & $26(5.9 \%)$ & $\mathrm{ns}$ \\
squeezing & $26(5 \%)$ & $4(5.12 \%)$ & $22(5 \%)$ & $\mathrm{ns}$ \\
typical* & $17(3.3 \%)$ & $4(5.13 \%)$ & $13(2.9 \%)$ & $\mathrm{ns}$ \\
pain* & $15(2.9 \%)$ & $1(1.28 \%)$ & $82(18.6 \%)$ & $\mathrm{ns}$ \\
miscellaneous & $94(18.1 \%)$ & $12(15.4 \%)$ & & \\
\hline * the characteristic of pain was not described in the records. &
\end{tabular}


Male-to-female ratio in this study was $82.7 \%: 17.3 \%$. The similar ratios were reported by other investigators. Zimmerman et al ${ }^{11}$ reported a ratio of $84.9 \%: 15.1 \%$ among 8839 cases of acute myocardial infarction in 1974-1979 in the USA, while Holt et al ${ }^{8}$ found a ratio of $73.8 \%: 26.14 \%$ among 2643 cases studied in 19681983 in the USA and Canada. In Framingham's study ${ }^{26}$ in a course of 26 years follow-up, the incidence of acute myocardial infarction among the males was tripled as compared to that of the females. In a study conducted at the National Cardiac Center in Jakarta, 1988-1989, Hanafiah reported a male-to-female rates of $99,1 \%$ to $0.1 \%{ }^{10}$ Our study confirmed the abovementioned reports, that the incidence of myocardial infarction was higher in the males with a male-tofemale ratio ranging from 3 to 5 , although a much higher ratio was observed in Hanafiah's study.

The prevalence of acute myocardial infarction patients under 45 years of age in this study was $14.6 \%$. Holt $^{8}$ reported a prevalence of $8 \%$ in patients under 45 years of age. A value of $1-8 \%$ was reported by Jakuwick in patients under 35 years of age. Hanafiah ${ }^{10}$ reported a prevalence of $10.17 \%$ in patients under 45 years of age. In the age group of under 45 years of age, the male-to-female ratio was $93.6 \%: 6.4 \%$ as compared to a ratio of $83.8 \%$ : $19.2 \%$ in the age group above 45 years. This lower prevalence of females attacked by acute myocardial infarction in the younger group showed a moderately significant statistical difference.

In Framingham's study in males aged $35-45$ years old, the incidence of coronary heart disease was $1.2 / 1000$ population while in the age group of $75-85$ years it increased to $46.8 / 1000$ population. The incidence of coronary heart disease rose after the age of 45 years. In the females suffering from CHD the increase was less frequent in comparison with that of premenopausal age. ${ }^{26}$

\section{Occupation}

In this study, it was found that private sector employee had the highest prevalence of acute myocardial infarction $(32.3 \%)$, far exceeding those with the other kinds of occupation. However, our study was not designed to answer this issue.

In a study performed by Morris comprising 18.000 civil servants in England, those who used their leisure times with physical activities $>7.5 \mathrm{cal} / \mathrm{m}$ for over 8 years life span, had a $50 \%$ decrease of relative risk of acute myocardial infarction. ${ }^{27}$

\section{Time of onset}

Acute myocardial infarction has circadian variability. In our study in which patients with time of onset less than 24 hours were analyzed, we found the peak incidence of acute myocardial infarction at approximately 09.00 a.m. This pattern was similar to TRIMM ${ }^{29}$ and GiISSI studies. ${ }^{30}$

The TRIMM study (Trigger and Mechanism of Myocardial Infarction $)^{29}$ reported a significantly higher prevalence of acute myocardial infarction between 06.00 to $09.00 \mathrm{a}$.m. The time of onset was defined as the time of the most severe symptom experienced for the first time by the patient. After adjustment with time of wake-up was made, the study showed that in three hours after wake-up the heart rate increased 1.8 to 2.4 times. In ISSI study, ${ }^{30}$ involving only patients with onset less than 6 hours, there was an increase in the frequency of anginal attacks in the morning and during the day. Fiquras and Lidon reported ${ }^{31}$ that these attacks occurred most frequently on $07.00-10.00$ and on $19.00-22.00$.

In this study, the principal risk factors in the male patients were smoking and stress, whereas in the females these factors included history of diabetes mellitus, glucose intolerance, hypertension and obesity. In Framingham's study, ${ }^{26}$ the most important risk factor for the males was smoking and for the females diabetes mellitus. This result was different from that of the present study in which hypertension was more prevalent in female acute myocardial infarction.

\section{Risk factors in patients under $\mathbf{4 5}$ years of age}

In this study, the most common risk factors in patients under 45 years old were smoking, positive family history and stress, while hypertension and diabetes mellitus were not as frequent as in older patients. This result confirmed the studies of Holt, ${ }^{8}$ Zimmerman $^{11}$ and Barbash ${ }^{12}$ where smoking was found as the most frequent risk factor in patients under 45 years of age. Barbash ${ }^{12}$ found that a positive family history was the second most important risk factor after smoking.

Some investigators found a positive family history as the principal risk factor in young age. Hanafiah encountered that stress was more prevalent in young acute myocardial infarction patients than in older patients. ${ }^{10}$ 
Hypertension and diabetes mellitus in young age were less important than in the older patients.

\section{Clinical manifestations}

In this study, chest pain was the most frequent complaint $(86.1 \%)$, but there were other complaints that also deserved attention such as breathlessness (5.6\%), epigastric pain (4.0\%), "severe conditions" (fainting, fatigue, severe illness, convulsion, shock, feet cyanosis) (3.1\%), and other miscellaneous complaint (palpitation, diarrhea, cold sweat, post-PTCA and without complaint) of $1.1 \%$. In their study, Harun et $\mathrm{al}^{35}$ found substernal chest pain as the chief complaint in $89 \%$ of their patients.

\section{Peak values of CK and CKMB enzymes}

Peak values of creatinine kinase $(\mathrm{CK})$ and creatinine kinase muscle brain (CK-MB) enzymes correlated with the extent of myocardial damage. ${ }^{36}$ This study encountered a peak value of CK enzyme of $925.33 \mu \mathrm{l}$ $(\mathrm{SD} \pm 1127.33 \mu \mathrm{l}$ ), while peak value of CKMB enzyme was $81.821 \mu 1(\mathrm{SD} \pm 176.96 \mu 1)$. The trend of peak values of CK and CKMB enzymes in patients under 45 years of age was higher than that of the older age. Statistically, this was not significant. Holt in his study found a peak value of CK in age group of under 45 years old to be higher than that in those above 45 years old, i.e., $1064(+816)$ : $826(+655),(P=0.001)$.

\section{Leucocyte}

As body responded to acute myocardial infarction, the leucocyte count wouldl increase. The magnitude of response was correlated with the extent of the inflammatory process and myocardial necrosis. ${ }^{37}$ Elevated periphery leucocyte count is associated with ventricular arrhythmia in initial phase of acute myocardial infarction. In this study, we found leucocytosis with a mean count of $12385 \mu \mathrm{l}(\mathrm{SD} \pm 5618 / \mu \mathrm{l})$. The mean leucocyte count of nonsurviving patients was higher than that of surviving patients, being $13.218 / \mu \mathrm{l}$ $(\mathrm{SD} \pm 4835 / \mu \mathrm{l})$ compared with $12.2239 / \mu \mathrm{l}$ (SD \pm $4435 / \mu \mathrm{l})$. However the difference was not statistically significant.

\section{Annual trend of acute myocardial infarction}

In the observation period from 1990 to 1994 , we did not find an increasing trend of acute myocardial infarction cases in patients under 45 years vs those above 45 years. Hanafiah reported a trend towards increasing age from $7 \%$ in 1985 to $17 \%$ in $1989 . .^{10}$
For the whole sample: the ages of male patients with acute myocardial infarction ranged from 14 to 85 years, (mean age $53.98 \pm 10.66$ years), whereas in the female patient ranged from 35 to 85 years, ( mean age $61.40 \pm 11.06$ years). Mean age of all patients was 55.26 years. Female patients were fewer than male patients, with a ratio of $17 \%: 83 \%$.

In the young age: the most prevalent risk factors in patients under 45 years of age were : smoking and stress, whereas risk factors of diabetes mellitus and hypertension were less common in the young than in the older age.

Conventional risk factors were: hypertension (30.9\%), history of diabetes mellitus $(13.5 \%)$, glucose intolerance $(25.5 \%)$, smoking $79,8 \%$, history of dys lipidemia $(12.5 \%)$, positive family history $(16.3 \%)$. Non-conventional factors were obesity $(35.1 \%)$. stress (64\%), and type A personality (54.6\%).

Chief complaints were: chest pain $(91.5 \%)$, breathlessness $(3.2 \%)$, epigastric pain $(3.2 \%)$, severe general conditions $(1.1 \%)$. Characteristics of chest pains were: pressure sensation (39.7\%), stabbing sensation (26.9\%), burning sensation (10.3\%), feeling of being squeeze $(5.1 \%)$.

There was no difference in the male-to-female ratio in patients under 45 years vs that of above 45 years from 1990 to 1994.

\section{REFERENCES}

1. Kannel WB, Thom TJ. Insidence, prevalence and mortality of Cardiovascular Disease, in Hurst JW(ed): The Heart $7^{\text {th }}$ edition, MC Graw-Hill 1990; 627-38.

2. Beaglehole R. Cardiovascular disease in developing countries. Br Med J 1992; 305: 1170-1.

3. Goto $Y$. The changing face of atherosclerotic disease in Japan, in Sheperd J, et all: Cardiovascular Disease: Current Perspective on the Asia-Pacific Region, Macckesfield UK Gardiner-Caldwell comm.Ltd, 1994:3-16.

4. National Household Survey on Health-Dept of Health, Indonesia 1985/86 and 1992. In ref 5:26-7.

5. Boedhi Darmojo R. Cardiovascular disease in Indonesia, in Current Perspective on the Asia Pacific Region. Macckesfield UK Gardiner-Caldwell comm.Ltd, 1994: 25-50.

6. Soewondo P, Waspadji S, Oemardi M, Harun S, Manurung D, Suyono S. Risk factor for cardiovascular disease among diabetics and inpaired glukosa intolerance (IGT) patients in Kayu Putih. Congress AFES VIII, Manila 1995.

7. Suyono S. Pidato Pengukuhan Sebagai Guru Besar FKUI Jakarta 1992 
8. Hoit BD, Gilpin EA, Henning $\mathrm{H}$, et al. Myocardial infarction in young patients : an analysis by age subsets. Circulation $1986 ; 74: 712-21$

9. Borgia MC, Savona M, Depada G, et al. Clinical study of myocardial infarction in young patients. Curr ther Res 1993;53(2): 235-46.

10. Hanafiah A. Myocardial infarction in young adults : Risk factors and clinical features. Majalah Kardiologi Indonesia 1990; 3:132-39.

11. Zimmerman FH, Cameron A, Fisher LD, Grace. Myocardial infarction in young adults: angiographic catheterization, risk factors and prognosis (Coronary Artery Surgery Study Registry). Am J Coll 1995;26(3):654-61.

12. Barbash, Modan WM, Diaz R, et al. Acute myocardial infarction in the young the role of smoking Eur Heart $\mathbf{J}$ 1995;16:3131-6.

13. Kannel WB, Mc Gel D, Gordon T. A general cardiovascular risk profile : The Framingham study. JAMA 1976; 36:46-51.

14. Wolfe MW, Vacek JL. Myocardial infarction in the young. Angiographic features and risk factor analysis of patient with myocardial infarction at or before the age of 35 years. Chest 1988;94(5):926-30.

15. Vane JR, Anggard EE, Boting RM. Regulatory functions of the vascular endothelium. N Engl J Med 1990;323:27-36.

16. Kapoor,AS: Assessment, risk stratification and prognosis of young patients after myocardial infarction. In ref 39:197.

17. Parish S, Collins R, Peto R, et al. Cigarette smoking for yields, and non fatal myocardial infarction 14000 cases and 32.000 controls in United Kingdom. Br.Med. J 1995; $311: 471-7$

18. Uhl GS, Farell PW. Myocardial infarction in young adults: Risk factors and natural history. Am Heart J 1983; 105:54853.

19. Friedlander Y, Kark JD, Stein Y. Family history as an indepedent risk factors for coronary heart disease. $\mathrm{Br}$ Heart J 1985;53:382-7.

20. Roncaglioni, Santoro L, D'Avanzo et al. Role of Family history in patients with myocardial infarction. An Italian case-control study. Circulation 1992;85:2065-72.

21. Dahlen GH, Guyton JR, Aftar M: Association of levels of lipoprotein $\mathrm{Lp}(\mathrm{aA})$, plasma lipids, and other lipoproteins with coronary artery disease decumented by angiography. Circulation 1986;74:758-65.

22. Scan AM. Lipoprotein (a).A genetic risk factor for premature coronary heart disease. JAMA 1992;267:3326-9.

23. Yonest JJ, Martin-Munley SS,Mchamara JR, et al. Familial lipoprotein disorders in patient with premature coronary artery disease. Circulation 1992;85:2025-33.
24. McKeque Dm, Ferrie JE, Pierpoint, et al. Association of early onser coronary heart disease in south Asian men with glucose intolerance and hyperinsulinemia. Circulation 1993:87:152-61.

25. Jalowiec DA,Hill JA, Myocardial infarction in the young and women, in Phepin CJ(ed): Acute Myocardial Infarction. Philadelphia, FA Davis company, 1989;197-206.

26. Lerner DJ, Kannel WB. Patterns of coronary heart disease morbidity and mortality in the sexes: A 26 year follow up of the Framingham population. Am Heart J 1986;111(2):38390.

27. Morris JN, Everitt MG, Pollard R, et al: Vigorous exercise in leisure time: Protection againts coronary heart disease. In ref 65:1486.

28. Rogers WJ, Bowlby LJ, Chandra NC et al. Treatment of myocardial infarction in the United States (1990 to 1993). Observations from the national registry of myocardial infarction. Circulation 1994;90(4):2130-14

29. Willich SN, Lowel H, Lewis M, et al. Association wake time and onset of myocardial infarction. TRIMM pilot study. Circulation 1991;84(6):VI-62-7.

30. Ruscone TG, Piccahga E,Gwzzetti S et al. Moming and monday: Critical periods for the onset acute myocardial infarction. The ISSI 2 study experience. Eur Heart J 1994; $15: 882-7$

31. Figueras J, Lidon RM. Circardian rhythm of angina in patients with unstable angina: relationship with extent of coronary reserve and ECG changes during pain. Eur Heart J 1994;15:753-60.

32. Mukhtar Z. Makna klinis dan prognosis lekositosis pada infark miokard akut. Laporan untuk mencapai sebutan spesialis I. Penyakit Jantung dan pembuluh darah. Program Pendidikan Dokter Spesialis I FKUI 1994:VII.

33. Greenland P, Reider-Reiss H, Goldbourt U et al. In hospital and a year mortality in 1.524 women after myocardial infarction. Comparison with 4.315 men. Circulation 1991;83:48491.

34. Wilkinson P, Kaji K, Ranjadayalan K et al. Acute myocardial infarction in women : survival analysis in first six months. BMJ 1994;309:566-9.

35. Harun S, Rochman AM, Panggabean MP. Diagnosis Infark Jantung Akut. Kumpulan Naskah Lengkap Simposium Penyakit Jantung Koroner. Bagian Ilmu Penyakit Dalam FKUI/RSCM Jakarta, 1980.

36. Hurst JW. Atherosclerotic coronary heart disease in Hurst JW(ed) : The Heart $7^{\text {th }}$ edition, Mc Graw Hill 1990;972-4.

37. Riceventi G, Servi SD. Mazzone et al. Increased neutrophil aggregability in coronary artery disease. Eur Heart J 1990;11:814-8. 